\title{
Fungicide Management of Faba Bean Gall (Olpidium viciae) in Ethiopia
}

\author{
Wulita Wondwosen ${ }^{1, a, *}$, Mashilla Dejene ${ }^{2, b}$, Negussie Tadesse $^{3, c}$, Seid Ahmed ${ }^{4, d}$ \\ ${ }^{1}$ Debre birhan Agricultural Research Center, P.O.Box: 112, Debre birhan, Ethiopia. \\ ${ }^{2}$ School of Plant Sciences, Haramaya University, P.O. Box 138, Dire Dawa, Ethiopia. \\ ${ }^{3}$ International Centre for Agricultural Research in the Dray Areas, P. O. Box: 5689, Addis Ababa, Ethiopia. \\ ${ }^{4}$ Biodiversity and Integrated Gene Management Program, ICARDA, Rabat Institutes, P.O. Box: 6299, Rabat 10112, Morocco
}

*Corresponding author

\begin{tabular}{l|l}
\hline A R T I C L E I N F O & A B S T R A C T \\
\hline Research Article & $\begin{array}{l}\text { Various biotic, abiotic and socio-economic factors negatively affect the productivity of the crop. } \\
\text { Among these, a new disease known as Faba bean galls (Olpidium viciae) has become a serious } \\
\text { threat to faba bean production and productivity in highland areas of central and northern Ethiopia. } \\
\text { Thus, field experiment was conducted in Lay Gorebela and Mush to assess the efficacies of } \\
\text { fungicides for the management of faba bean gall under natural infection. Six fungicides were } \\
\text { evaluated alongside control in randomized complete block design in three replications. Fungicides } \\
\text { showed different levels of efficiency at both locations in both seasons. In 2014/15, the highest } \\
\text { percent severity index and area under disease progress curve were calculated from control plots at } \\
\text { Accepted : } 12 / 06 / 2019 \\
\text { both locations. At Lay Gorebela, higher grain yields were recorded from Metalaxyl } 8 \%+\text { Mancozeb } \\
64 \% \text { WP and Triadimefon 250 g/L sprayed plots whereas plots sprayed with Metalaxyl } 8 \%+ \\
\text { Mancozeb } 64 \% \text { WP gave higher yield at Mush. Similar trends in percent severity index and grain } \\
\text { yield were observed with control treatment in 2015/16. Percent severity index and area under disease } \\
\text { progress curve were negatively correlated with grain yield and positively correlated with each other } \\
\text { at both locations and seasons. Partial budget analysis indicated as Triadimefon 250 g/L and } \\
\text { Metalaxyl } 8 \%+\text { Mancozeb } 64 \% \text { WP were cost-effective. The chemical treatment could be used as } \\
\text { a short-term control strategy, and a component in integrated management of faba bean galls. }\end{array}$ \\
$\begin{array}{l}\text { Keywords: } \\
\text { Olpidium viciae }\end{array}$ \\
$\begin{array}{l}\text { A isease progress rate } \\
\text { Percent severity index }\end{array}$
\end{tabular}

wulitawondwosen@gmail.com

negussie_ab@yahoo.com

\section{Introduction}

Faba bean (Vicia faba L.) is grown in many countries as a rain-fed and irrigated crop for human food and animal feed and plays important roles in the national economy and agricultural production in various ways. Faba bean is a leading protein crop in and covered over half a million ha and production of close to one million tonnes of grain and 1.2 million tonnes of straw (CSA, 2014).

Despite the availability of high yielding varieties, the average national yield of faba bean is $<2$ tonnes/ha (CSA, 2014). Various biotic, abiotic and anthropogenic factors have attributed to the low productivity of the crop. Many diseases affect faba bean yield and quality, but only a few of them cause economic damage (Samuel et al., 2008), Recently, a disease known as Faba bean galls has become a serious threat to faba bean production and productivity as well as threatening faba bean genetic resources in the central and northern mountain regions and plateaus of the country with an average elevation of between 2500 and $3300 \mathrm{~m}$ whose mean temperature ranges from 13 to $20^{\circ} \mathrm{C}$. According to Endale et al. (2014), the disease became more severe at an altitude above 2400 m.a.s.l. and higher rain fall. The disease can cause yield losses as high as $100 \%$ during seasons favouring disease development (Beyene and Wulita, 2012). The disease was first reported as "faba bean gall" in Degem, Bash area of Menz Mama and MojanaWedera district in North Shoa, Ethiopia in 2011 (Beyene and Wulita, 2012; Dereje et al., 2012) and now spread in different parts of central and northern highlands of the country (Endale et al., 2014; Teklay et al., 2014; Beyene, 2015).

The disease affects all above ground plant parts and gall symptoms mainly appear on leaves and stems and later affects pods. The initial symptoms appear as green and depressed on one side of the leaf and swelling like tumour on the reverse side and become brownish and extend to the stem (Figure 1). The spot immediately changes to brown lesion and covers the whole lower leaves and the stems. The galls change from circular to slightly irregular shape, where mature leaves develop due coalescing necrotic galls. 
The disease was first recorded in Japan in 1912 as faba bean galls (Olpidium viciae Kusano), and also it is a key disease in highlands of Songpan, Xiaojin, Maekang Sichuan Gansu, Tibet and Shanxi provinces of China (Xing, 1984; Li-juan et al. 1993). In 2014, Huazhi Ye (2014) identified Olpidium viciae on faba bean leaf and stem samples with galls (blisters) from Ethiopia by means of microscopic examination. So far, a little has been known about Faba bean galls epidemics and there are no recommendations on the management of the disease in Ethiopia. Unless appropriate strategy is devised to curb the spread of the disease and manage it in timely manner, the disease would continue to affect vast areas of crop in major faba bean producing regions shortly in the country. Thus, the objectives of this study were to assess the efficacies of selected fungicides for the management of faba bean galls.

\section{Materials and Methods}

Description of the Experimental Site

The study was conducted on farmers' fields in BasonaWorana and Ankober Districts, North Shoa Zone, at Mush and Lay Gorebela villages in 2014/15 and 2015/16 main cropping seasons (Figure 1). The area is suitable for disease development and farmers lose their faba bean crops every season since its occurrence in the area. The altitude of Mush site was 2975 m.a.s.l. with average annual rainfall of $897.8 \mathrm{~mm}$ and mean minimum and maximum temperatures of 6.1 and $19.7^{\circ} \mathrm{C}$, respectively. Lay Gorebela village is located at an altitude of $3120 \mathrm{~m}$ a.s.l. with mean annual rainfall of $1793 \mathrm{~mm}$ and average minimum and maximum temperatures of 13 and $27^{\circ} \mathrm{C}$, respectively.

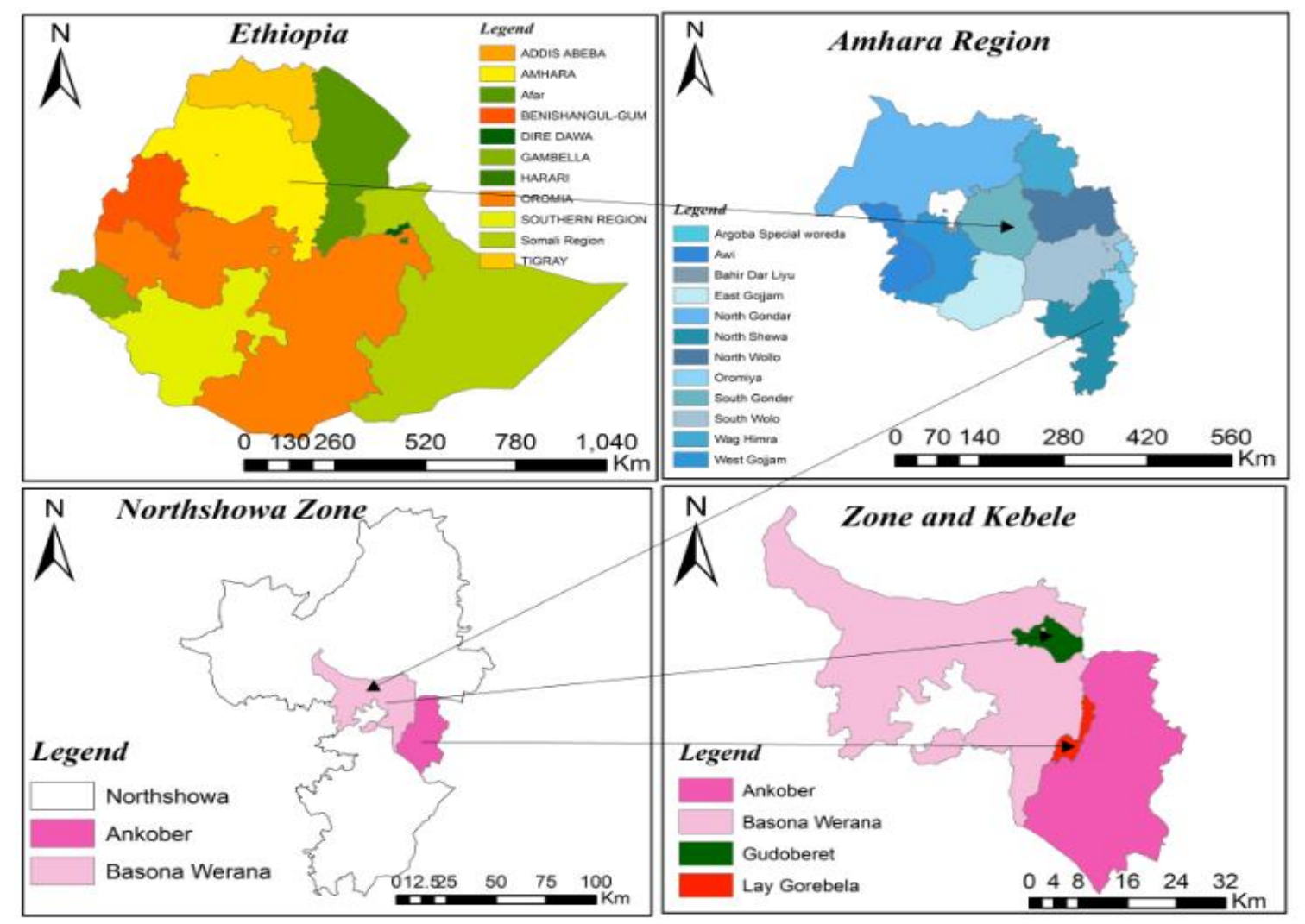

Figure 1 Map of the experimental sites

\section{Experimental Materials, Design and Procedures}

Five fungicides (four foliar and one seed treatment) were evaluated along with untreated control plot. A local faba bean variety from each village was used for the fungicide management tests.

A plot size of $3.2 \mathrm{~m}^{2}$ with a spacing of $1 \mathrm{~m}$ between plots and $1.5 \mathrm{~m}$ between replications were used in the experiment. Four rows (20 plants/row) with a spacing of 40 $\mathrm{cm}$ was used. The treatments were arranged in a randomized complete block design with three replications. Fertilizer DAP (46 kg Phosphorus and $18 \mathrm{~kg} / \mathrm{ha}$ nitrogen) was applied at planting. Planting was done on July 2, 2014 and June 24, 2015 at Mush village and July 3, 2014 and June 25, 2015 at Gorebela village. The foliar spray fungicides were applied three times using knapsack sprayer starting from the first appearance (at vegetative stage of the crop) of the disease and water was sprayed on control plots.

\section{Data collection}

Disease severity: Disease severity was recorded on 20 randomly selected plants in the two central rows of each plot starting from the onset of the disease and repeated after every 10 day intervals. A $0-9$ scale was used where $0=$ no disease symptom observed, $1=<2 \%$ plant parts infected, $2=2-5 \%$ plant parts infected, $3=6-10 \%$ plant parts infected, $4=11-25 \%$ plant parts infected, $5=26-50 \%$ plant parts infected, $6=51-75 \%$ plant parts infected, $7=$ $76-90 \%$ plant parts infected, $8=91-99 \%$ plant parts infected, $9=100 \%$ plant parts infected (Ding et al., 1993). Disease severity scores were converted into a percentage severity index (PSI) for analysis (Wheeler, 1969).

$$
\text { PSI }=\frac{\mathrm{Snr}}{\mathrm{Npr} \times \mathrm{Msc}} \times 100
$$


In the formula, Snr is the sum of numerical ratings, $\mathrm{Npr}$ is number of plant rated, Msc is the maximum score of the scale. Means of the severity from each plot were used in data analysis.

Area under disease progress curve (AUDPC): AUDPC was calculated for each plot using the formula of Shaner and Finney (1977) and expressed in \%-days.

$$
\mathrm{AUDPC}=\sum_{\mathrm{i}=1}^{\mathrm{n}-1} 0.5\left(\mathrm{X}_{\mathrm{i}+1}+\mathrm{X}_{\mathrm{i}}\right)\left(\mathrm{t}_{\mathrm{i}+1}-\mathrm{t}_{\mathrm{i}}\right)
$$

Where $X_{i}$ is the cumulative disease severity at the $i^{\text {th }}$ observation; the independent variable ' $x$ ' indicates the AUDPC level in percentage; $t_{i}$ is the time (days after planting) at the $\mathrm{i}^{\text {th }}$ observation and $\mathrm{n}$ is the total number of observations.

Disease progress rate: Logistic, $\ln [\mathrm{Y} /(1-\mathrm{Y})]$ (Van der Plank, 1963) and Gompertz, $-\ln [-\ln (Y)]$ (Berger, 1981) models were compared for the estimation of disease development from each treatment. The goodness of fit of the models was tested using the coefficient of determination $\left(\mathrm{R}^{2}\right)$ and residuals (SE) (Campbell and Madden, 1990).

\section{Crop Parameters}

Data on $90 \%$ maturity, plant height $(\mathrm{cm})$, number of pods per plant, number of seeds per pod, hundred seed weight $(\mathrm{g})$ and total grain yield $\left(\mathrm{t} \mathrm{h}^{-1}\right)$ were recorded.

Percent relative grain yield loss (RYL) was calculated as follows:

$$
\operatorname{RYL}(\%)=\frac{(Y p-Y t)}{Y p} \times 100
$$

Where, RYL = relative yield loss in percent, $\mathrm{Yp}=$ yield from the maximum protected plots and $\mathrm{Yt}=$ yield from other plots

\section{Data Analyses}

Data on PSI, AUDPC, disease progress rate, hundred seed weight and yield were subjected to analysis of variance to determine the treatment effects by using SAS software (SAS, 2002). Mean comparisons for treatment parameters was done using Duncan multiple range test (DMRT) at 5\% level of significance.

\section{Cost - Benefit Analysis}

Prices of faba bean seed (Birr ton ${ }^{-1}$ ) from a local market in each village and total sale from one hectare were computed. Price of fungicides, labor costs for chemical application and equipment were also recorded. Partial budgeting was used to assess profitability of any new technologies to be imposed to the agricultural business (CIMMYT, 1988).

\section{Result and Discussion}

\section{Disease Parameters}

Disease severity: The newly emerged faba bean diseases "faba bean gall" was first observed at vegetative stage at both locations in 2014/15 cropping season and at flowering stages in 2015/16 cropping season in all plots.
Faba bean gall disease severity varied in the two seasons' and locations, where severity was high in 2014/15 cropping season due to favorable weather condition for disease development. At the initial assessment dates, fungicides did not showed significant $(\mathrm{P}>0.05)$ variation from each other in PSI at both locations (Table 2). On the other hand, at the final assessment dates, fungicide application showed significant differences in PSI at both locations and years.

All fungicides did not provide enough protection in reducing disease severity but the seed treatment fungicide showed poor performance in both locations and seasons. In the 2014/15 main cropping season, the highest (67.41 and 72. 59\%) final percent severities were recorded from unsprayed control plots at Lay Gorebela and Mush at 119 and 111 DAS (days after planting), respectively (Table 1). Similarly, in 2015/16, the highest (52.78 at Lay Gorebela at 134 DAS and $63.52 \%$ Mush at 111 DAS) percent severities were recorded from unsprayed control plots at the final assessment date. This current finding coincides with the result of DBARC (2015); Alemu and Tadele (2017) who reported that foliar applied fungicides reduced the severity of faba bean galls on faba bean compared to the unsprayed control plots. On the other hand, the corresponding minimum final gall severities (50.37 and $41.85 \%$ ) were recorded from plots sprayed with Metalaxyl $8 \%+$ Mancozeb 64\% WP at lay Gorebela and Mush in 2014/15. Accordingly, application of Metalaxyl 8\%+ Mancozeb 64\% WP reduced gall severities by 25.28 and $42.35 \%$ from unsprayed control plots at Lay Gorebela and Mush in 2014/15 cropping season.

In general, in this study, the newly emerged disease "faba bean gall" epidemics on faba bean occurred at both locations in both years. The pre-spray disease assessment showed a uniform distribution of the disease in all the plots in the trial areas before spraying. However, none of the treatments completely controlled the development of the disease; the disease increased more rapidly on unsprayed control plots than on most sprayed plots at both locations, and showed significantly higher "gall" severity on unsprayed plots than on the sprayed plots in all assessments, followed by Fludioxonil treated plots. The current study result is in agreement with the finding of DBARC (2015), which reported that seed dressing fungicides were not effective against this disease.

Area under disease progress curve (AUDPC): Analysis of variance showed there was a significant difference in AUDPC both at Lay Gorebela and Mush in both seasons (Table 2). At Lay Gorebela, the highest (3027.5\%-days in 2014/15 and 1002.8\%-days in 2015/16) AUDPC values were calculated from unsprayed control plots. Similarly, the corresponding AUDPC values of 3262.6 and 2466.7\%days were calculated from unsprayed control plots at Mush in 2014/15 and 2015/16 cropping seasons. On the other hand, the lowest AUDPC values were calculated from plots sprayed with Metalaxyl 8\% + Mancozeb $64 \%$ WP at both Lay Gorebela and Mush in 2014/15 cropping season. Likewise, the lowest (430.1 and $475.7 \%$-days) AUDPC values were obtained from plots sprayed with Metalaxyl 8\% + Mancozeb $64 \%$ WP and Triadimefon at Ankober, respectively, in 2015/16 (Table 3). Belachew (2016) also reported three times spray of systemic fungicides has been recorded highly effective in reducing area under disease progress curve of faba bean gall disease. 
Table 1 Fungicides used in the experiment against faba bean gall disease

\begin{tabular}{l|ll}
\hline \multicolumn{1}{c|}{ Commercial name } & \multicolumn{1}{|c}{ Active ingredient } & Rate of application(in active ingredient base) \\
\hline Bayleton 25 WPyy & Triadimefon & $125 \mathrm{~g} \mathrm{ha}^{-1}$ \\
Indofil M-45y & Mancozeb 80\% & $1.6 \mathrm{~kg} \mathrm{ha}^{-1}$ \\
Odeon 82.5 WDGy & Chlorothalonil & $2.05 \mathrm{~kg} \mathrm{ha}^{-1}$ \\
Metalaxyl-M 68\% WG & $1.36 \mathrm{~kg} \mathrm{ha}^{-1}$ \\
Matco yy & Metalaxyl-M & $1.8 \mathrm{~kg} \mathrm{ha}$ \\
Celest Top* & Metalaxyl 8\% + Mancozeb 64\% WP & $2 \mathrm{ml} / \mathrm{kg} \mathrm{seed}^{-1}$ \\
Control & Fludioxonil & \\
\hline
\end{tabular}

*: Used as seed treatment, y: sprayed at 7 days interval and yy: sprayed at 14 days interval

Table 2 Effect of fungicide application on faba bean gall severity

\begin{tabular}{l|crrr}
\hline \multirow{2}{*}{\multicolumn{1}{c|}{ Fungicides }} & \multicolumn{3}{c}{ Final gall mean percent severity index (PSI) } \\
\cline { 2 - 4 } & \multicolumn{2}{c}{ Lay Gorebela } & \multicolumn{2}{c}{ Mush } \\
\cline { 2 - 4 } & $2014 / 15$ & $2015 / 16$ & $2014 / 15$ & $2015 / 16$ \\
\hline Chlorothalonil & $55.19^{\mathrm{c}}$ & $25.19^{\mathrm{c}}$ & $50.13^{\mathrm{cd}}$ & $52.41^{\mathrm{b}}$ \\
Mancozeb80 \% WP & $53.33^{\mathrm{c}}$ & $30.18^{\mathrm{bc}}$ & $56.85^{\mathrm{bc}}$ & $52.41^{\mathrm{b}}$ \\
Triadimefon 250 g/l & $54.82^{\mathrm{c}}$ & $30.36^{\mathrm{bc}}$ & $47.78^{\mathrm{cd}}$ & $50.56^{\mathrm{bc}}$ \\
Metalaxyl-M 68\% WG & $54.82^{\mathrm{c}}$ & $22.56^{\mathrm{c}}$ & $47.41^{\mathrm{cd}}$ & $50.56^{\mathrm{bc}}$ \\
Metalaxyl 8\% + Mancozeb 64\% WP & $50.37^{\mathrm{d}}$ & $22.59^{\mathrm{c}}$ & $41.85^{\mathrm{d}}$ & $45.74^{\mathrm{c}}$ \\
Fludioxonil & $61.11^{\mathrm{b}}$ & $42.22^{\mathrm{ab}}$ & $63.03^{\mathrm{b}}$ & $59.63^{\mathrm{a}}$ \\
Control & $67.41^{\mathrm{a}}$ & $52.78^{\mathrm{a}}$ & $73.00^{\mathrm{a}}$ & $63.52^{\mathrm{a}}$ \\
Mean & 56.24 & 32.27 & 53.28 & 53.55 \\
CV $(\%)$ & 5.41 & 27.69 & 9.04 & 6.20 \\
\hline
\end{tabular}

Means shown with the same letters were not significantly different from each other

Table 3 Effects of fungicides on AUDPC (\% days) on faba bean gall

\begin{tabular}{|c|c|c|c|c|c|c|c|c|}
\hline \multirow{3}{*}{ Fungicides } & \multicolumn{4}{|c|}{ AUDPC (\%-days) } & \multicolumn{4}{|c|}{ Infection rate per day (gompit day ${ }^{-1}$ ) } \\
\hline & \multicolumn{2}{|c|}{ Mush } & \multicolumn{2}{|c|}{ Lay Gorebela } & \multicolumn{2}{|c|}{ Mush } & \multicolumn{2}{|c|}{ Lay Gorebela } \\
\hline & $2014 / 15$ & $2015 / 16$ & $2014 / 15$ & $2015 / 16$ & $2014 / 15$ & $2015 / 16$ & $2014 / 15$ & $2015 / 16$ \\
\hline Chlorotalonil & $2106.5^{\mathrm{bc}}$ & $1938.0_{\mathrm{b}}$ & $2120.4^{\text {cd }}$ & $504.6^{\mathrm{bc}}$ & $0.035^{\mathrm{b}}$ & $0.076^{\mathrm{b}}$ & $0.037^{\mathrm{ab}}$ & $0.008^{\mathrm{cd}}$ \\
\hline eb $80 \%$ WP & $2154.5^{\mathrm{bc}}$ & $1914.8^{b}$ & $2142.8^{c}$ & $582.4^{\mathrm{bc}}$ & $0.034^{\mathrm{b}}$ & $0.055^{\mathrm{b}}$ & $0.032^{\mathrm{b}}$ & $0.010^{\mathrm{c}}$ \\
\hline Triadimefon $250 \mathrm{~g} / 1$ & $1723.1^{\mathrm{cd}}$ & $1850.0^{\mathrm{b}}$ & $2049.8^{\mathrm{cd}}$ & $475.7^{\mathrm{c}}$ & $0.022^{\mathrm{c}}$ & $0.047^{\mathrm{b}}$ & $0.026^{\mathrm{c}}$ & $0.004^{\mathrm{d}}$ \\
\hline Metalaxyl-M 68\% WG & $1806.3^{\mathrm{cd}}$ & $1907.4^{\mathrm{b}}$ & $2080.1^{\mathrm{cd}}$ & $514.8^{\mathrm{bc}}$ & $0.022^{c}$ & $0.052^{\mathrm{b}}$ & $0.026^{\mathrm{c}}$ & $0.005^{\mathrm{d}}$ \\
\hline Metalaxyl 8\%+Mancozeb 64\% WP & $1450.7^{\mathrm{d}}$ & $1764.8^{b}$ & $1901.0^{\mathrm{d}}$ & $430.1^{c}$ & $0.021^{\mathrm{c}}$ & $0.052^{\mathrm{b}}$ & $0.024^{\mathrm{c}}$ & $0.005^{\mathrm{d}}$ \\
\hline Fludioxonil & $2432.3^{\mathrm{b}}$ & $2384.3^{\mathrm{a}}$ & $2469.3^{b}$ & $744.4^{\mathrm{b}}$ & $0.039^{\mathrm{a}}$ & $0.167^{\mathrm{a}}$ & $0.038^{\mathrm{a}}$ & $0.015^{\mathrm{b}}$ \\
\hline Control & $3262.6^{\mathrm{a}}$ & $2466.7^{\mathrm{a}}$ & $3027.5^{\mathrm{a}}$ & $1002.8^{\mathrm{a}}$ & $0.043^{\mathrm{a}}$ & $0.174^{\mathrm{a}}$ & $0.039^{\mathrm{a}}$ & $0.021^{\mathrm{a}}$ \\
\hline Mean & 2133.714 & 2032.28 & 2255.84 & 607.84 & 0.031 & 0.174 & 0.032 & 0.021 \\
\hline $\mathrm{CV}(\%)$ & 13.66 & 7.41 & 5.79 & 23.23 & 7.73 & 7.40 & 8.27 & 25.27 \\
\hline
\end{tabular}

Means shown with the same letters were not significantly different from each other

Rate of disease progress: The rate of disease progress was significantly $(\mathrm{P}<0.05)$ different among treatments at both locations and years (Table 3$)$. The highest (0.043 gompit per day at Mush and 0.039 gompit per day at Lay Gorebela) disease progress rates were recorded from the unsprayed control plots in 2014/15 cropping season. On the other hand, in 2015/16, faba bean gall progressed at the rate of 0.17 gompit per day on unsprayed and Fludioxonil treated plots at Mush, while it was 0.021 gompit per day on unsprayed control plots at Lay Gorebela. Generally, faba bean galls progress rate was faster on the unsprayed control and Fludioxonil treated plots at Ankober in both seasons. Similarly, the rate of progress of faba bean galls was faster on unsprayed control in 2014/15 and Fludioxonil treated and unsprayed control plots 2015/16 cropping season at Mush. However, on Metalaxyl 8\% + Mancozeb 64\% and Triadimefon sprayed plots the disease progress rate was low as compared to the other treatments at both locations in both seasons.

\section{Crop Parameters}

Days to $90 \%$ maturity and plant height: Fungicide application showed significant $(\mathrm{P} \leq 0.05)$ difference in $90 \%$ days to maturity at both locations in both study years. In 2014/15, the unsprayed control plots matured significantly in shortest periods, i.e. 180.00 days to maturity at Lay Gorebela and 138.67 days to maturity at Mush. Similarly, unsprayed control plots took the consequent shortest periods of 157 and 124.33 days to maturity at Lay Gorebela and Mush in 2015/16. This might be due to the higher disease pressure on unsprayed control plots than on the treated plots. Also, unsprayed control plots took significantly shorter periods to physiological maturity, i.e. the crop matured in a relatively shorter period at Mush than at Lay Gorebela. This might be due to the higher disease pressure at Mush than at Lay Gorebela associated with the variation in environmental condition and the varieties used at each location. 
Plant height was significantly $(\mathrm{P} \leq 0.01)$ different among the treatments at both locations in both season experiments. The shortest (109.93 $\mathrm{cm}$ at Lay Gorebela and $55.67 \mathrm{~cm}$ at mush) plant heights were obtained from the unsprayed control plots in 2014/15 cropping season. Likewise, the shortest plants heights of 64.53 at Mush and $64.67 \mathrm{~cm}$ Lay Gorebela were recorded from unsprayed control plots in $2015 / 16$. On the other hand, the tallest $(75.17 \mathrm{~cm}$ in $2014 / 15$ and $83.20 \mathrm{~cm}$ in 2015/16) plant heights were obtained from plots sprayed three times with Metalaxyl $8 \%$ + Mancozeb 64\% WP at mush. The result of this study is in agreement with the finding of DBARC (2015), which reported that the faba bean gall significantly reduced the height of the faba bean crop.

Numbers of pod per plant and seeds per pod: The number of pods per plant was significantly different among the fungicides, while the number of seeds per pod did not show significant variation at both locations in two seasons. The lowest mean numbers i.e. 19.00 at mush and 30.40 at Lay Gorebela pods per plant were obtained from the unsprayed control plots in 2014. Also, in 2015, the lowest (19.57 and 13.33) numbers of pods per plant were recorded from unsprayed control plots at Lay Gorebela and Mush, correspondingly.

Grain yield and hundred seed weight: Significant $(\mathrm{P} \leq 0.05)$ variations were observed among the fungicides in grain yield and hundred seed weight of the crop at both locations and seasons (Table 4). Grain yield was significantly increased by fungicide sprays at both seasons and seasons. At Lay Gorebela, the lowest (3.02 $\mathrm{t} \mathrm{ha}^{-1}$ in $2014 / 15$ and $2.78 \mathrm{t} \mathrm{ha}^{-1}$ in 2015/16) grain yield were recorded from unsprayed control plots, while the corresponding (2.31 and $2.17 \mathrm{t} \mathrm{ha}^{-1}$ ) yield obtained from unsprayed control plots. Generally, all fungicide-treated plots gave a higher grain yield than the unsprayed control plots. However, the plots treated with the Fludioxonil could not give significantly $(\mathrm{P}<0.05 \%)$ different yield than the unsprayed plots at both locations.

Significantly lowest i.e. 32.4 and $30.63 \mathrm{~g}$ seed weights were obtained from the unsprayed control plots at Lay Gorebela and Mush, respectively, in 2014/15. Also, hundred seeds weight of $35.33 \mathrm{~g}$ at Lay Gorebela and $28 \mathrm{~g}$ at Mush were recorded from unsprayed control plots in 2015/16 cropping season.

\section{Relative Yield Loss in Grain (RYL)}

In the untreated faba bean plots, relative seed yield loss were notably higher (Table 4 ). The highest (28.24\% at Lay Gorebela and $43.79 \%$ at Mush) relative yield losses occurred on the unsprayed control plots in 2014/15 cropping season. On the other hand, the subsequent low yield loss of 2.50 and $10.79 \%$ were recorded from plots sprayed three times with Triadimefon $250 \mathrm{~g} / \mathrm{l}$ at Lay Gorebela and Mush in the 2014/15. Also, the maximum $47.97 \%$ at Lay Gorebela and $29.97 \%$ at Mush relative grain yield reduction due to "faba bean galls" were recorded from unsprayed plots in 2015/16. Belachew (2016) stated that relative yield loss due to faba bean gall disease was higher on unsprayed plots of different faba bean cultivars.

Generally, in 2015/16 cropping season, 92.17 and $42.81 \%$ yield increase over unsprayed control plots were calculated from plots sprayed with Metalaxyl 8\% + Mancozeb 64\% WP and Triadimefon at Mush and Lay
Gorebela, respectively. While, the corresponding highest yield increases of 40.1 and $77.92 \%$ were obtained from plots sprayed with Metalaxyl 8\% + Mancozeb 64\% WP at Lay Gorebela and Mush in the 2014/15 main cropping season.

\section{Association of Disease Parameters with Yield}

Percent disease severity and AUDPC had highly significant negative correlation coefficients with yield, while AUDPC and severity themselves were highly and positively correlated with each other at both locations in both seasons (Table 5).Samuel et al. (2010), also reported that chocolate spot severity and AUDPC was negatively correlated with grain yield. In 2014/15, severity had correlation coefficients of $r=-0.70$ and $r=-0.80$ with yield at Lay Gorebela and Mush, whereas AUDPC had correlation coefficients of $r=$ 0.74 and $r=-0.79$ with yield at Lay Gorebela and Mush. Also, Sul et al. (2006), stated the terminal disease severity and AUDPC were very important in determining the extent of losses in yield and yield components and the observed levels of the disease had a considerable adverse effect on grain yield of the crops. Likewise, AUDPC had negative correlation coefficients of $r=-0.06$ at Mush and $r=-0.76$ at Lay Gorebela in 2015/16 cropping season, while, AUDPC and severity themselves had a correlation coefficient of ( $\mathrm{r}=$ 0.89 and 0.96 at Lay Gorebela) and $(r=0.95$ and 0.97 at Mush) in 2014/15 and 2015/16.

Regression analysis of the final severity as a predictor to yield (dependent variable) showed a significant $(\mathrm{P} \leq 0.002)$ relationship at both locations and years. The regression equation: Yield $\left(\mathrm{t} \mathrm{ha}^{-1}\right)=-0.050 \mathrm{x}+6.1,\left(\mathrm{R}^{2}=93.5 \%, \mathrm{P}=0.000\right)$ demonstrated a reduction of about $0.050 \mathrm{t} \mathrm{ha}^{-1}$ grain yield with the increase of $1 \%$ severity at Mush in 2014/15. Similarly, the regression equation: Yield $\left(\mathrm{t} \mathrm{ha} \mathrm{ha}^{-1}\right)=$ $0.0675 \mathrm{x}+7.8,\left(\mathrm{R}^{2}=88.4 \%, \mathrm{P}=0.002\right)$ illustrated the loss of about $0.0675 \mathrm{t} \mathrm{ha}^{-1}$ grain yield with the increase of $1 \%$ severity at Lay Gorebela in 2014/15 cropping season.

\section{Cost-benefit Analysis}

Results from the assessment of economic returns in this study indicated that fungicide application for faba bean gall management was profitable. The highest (ETB 31204.69 $\mathrm{ha}^{-1}$ at Lay Gorebela) and (ETB $30257.91 \mathrm{ha}^{-1}$ Mush) net benefits were obtained from the plots sprayed three times with Metalaxyl 8\% + Mancozeb 64\% WP as compared to unsprayed control plots in the 2014/15 cropping season (Table 6 and 7). On the other hand, in 2015/16, the corresponding highest (ETB $47215.5 \mathrm{ha}^{-1}$ ) and (ETB 49008 $\mathrm{ha}^{-1}$ ) net benefits were obtained from the plots sprayed three times with Triadimefon $250 \mathrm{~g} / \mathrm{l}$ at Lay Gorebela and Mush. Also, the next highest net benefit were obtained from plots sprayed with Triadimefon $250 \mathrm{~g} / 1$ and Metalaxyl $8 \%$ + Mancozeb 64\% WP in 2014/15 and 2015/16 main cropping season, respectively. Beyene and Abiro (2016) also reported application of bayleton and mancozeb fungicides against faba bean gall disease were more profitable than unsprayed control plots.

In line with this result, Belachew (2016) reported that three times spraying of fungicides on local cultivar resulted the maximum marginal rate of returns compared to unsprayed control plots. Also, Rechcing and Rechcing (1997) stated that fungicides are used because they provide effective and reliable disease control, deliver production in the form of crop yield and quality at an economic price and can be used safely. 
Table 4 Effect of fungicide application on yield and hundred seed weight of faba bean

\begin{tabular}{|c|c|c|c|c|c|c|}
\hline \multirow{3}{*}{ Fungicides } & \multicolumn{6}{|c|}{ Lay Gorebela } \\
\hline & \multicolumn{2}{|c|}{ Yield $\left(\mathrm{t} \mathrm{ha}^{-1}\right)$} & \multicolumn{2}{|c|}{ RYL (\%) } & \multicolumn{2}{|c|}{ Hundred Seed Weight (g) } \\
\hline & $2014 / 15$ & $2015 / 16$ & $2014 / 15$ & $2015 / 16$ & $2014 / 15$ & $2015 / 16$ \\
\hline Chlorothalonil & $3.79^{\mathrm{ab}}$ & $3.12^{\mathrm{bc}}$ & 10.40 & 21.41 & $35.53^{\mathrm{abc}}$ & $36.53^{\mathrm{bc}}$ \\
\hline Mancozeb $80 \%$ WP & $3.78^{\mathrm{b}}$ & $3.25^{\mathrm{bc}}$ & 17.89 & 18.14 & $34.30^{\mathrm{c}}$ & $36.63 \mathrm{a}^{\mathrm{bc}}$ \\
\hline Triadimefon $250 \mathrm{~g} / 1$ & $4.14^{\mathrm{a}}$ & $3.97^{\mathrm{a}}$ & 2.05 & 0.00 & $36.23^{\mathrm{ab}}$ & $36.80^{\mathrm{ab}}$ \\
\hline Metalaxyl-M 68\% WG & $3.84^{\mathrm{ab}}$ & $3.30^{\mathrm{abc}}$ & 9.14 & 16.88 & $35.57^{\mathrm{abc}}$ & $36.03^{\mathrm{bcd}}$ \\
\hline Metalaxyl 8\% + Mancozeb 64\% WP & $4.23^{\mathrm{a}}$ & $3.49^{\mathrm{ab}}$ & 0.00 & 12.09 & $36.50^{\mathrm{a}}$ & $37.57^{\mathrm{a}}$ \\
\hline Fludioxonil & $3.47^{\mathrm{bc}}$ & $2.87^{\mathrm{bc}}$ & 10.56 & 27.71 & $34.73^{\mathrm{bc}}$ & $35.70^{\mathrm{cd}}$ \\
\hline Control & $3.02^{\mathrm{c}}$ & $2.78^{\mathrm{c}}$ & 28.53 & 29.97 & $32.40^{\mathrm{d}}$ & $35.33^{c}$ \\
\hline Mean & 3.76 & 3.25 & & & 35.04 & 36.37 \\
\hline $\mathrm{CV}(\%)$ & 9.43 & 12.26 & & & 2.65 & 1.49 \\
\hline \multirow{3}{*}{ Fungicides } & \multicolumn{6}{|c|}{ Mush } \\
\hline & Yield $\left(\mathrm{t} \mathrm{ha}^{-1}\right)$ & & RYL $(\%)$ & & Hundred $\mathrm{Se}$ & Weight $(\mathrm{g})$ \\
\hline & $2014 / 15$ & $2015 / 16$ & $2014 / 15$ & $2015 / 16$ & $2014 / 15$ & $2015 / 16$ \\
\hline Chlorothalonil & $3.50^{\mathrm{ab}}$ & $3.30^{\mathrm{ab}}$ & 14.84 & 20.86 & $33.30^{\mathrm{a}}$ & $30.77^{\mathrm{abc}}$ \\
\hline Mancozeb $80 \% \mathrm{WP}$ & $3.38^{\mathrm{b}}$ & $3.46^{\mathrm{a}}$ & 23.22 & 17.03 & $32.47^{\mathrm{ab}}$ & $31.13^{\mathrm{abc}}$ \\
\hline Triadimefon $250 \mathrm{~g} / 1$ & $3.67^{\mathrm{ab}}$ & $4.12^{\mathrm{a}}$ & 10.79 & 1.20 & $33.57^{\mathrm{a}}$ & $32.3^{\mathrm{ab}}$ \\
\hline Metalaxyl-M 68\% WG & $3.56^{\mathrm{ab}}$ & $3.69^{\mathrm{a}}$ & 13.46 & 11.51 & $33.13^{\mathrm{a}}$ & $33.3^{\mathrm{a}}$ \\
\hline Metalaxyl 8\% + Mancozeb 64\% WP & $4.11^{\mathrm{a}}$ & $4.17^{\mathrm{a}}$ & 0.00 & 0.00 & $33.37^{\mathrm{a}}$ & $33.97^{\mathrm{a}}$ \\
\hline Fludioxonil & $3.14^{\mathrm{b}}$ & $3.26^{\mathrm{ab}}$ & 23.52 & 27.91 & $32.00^{\mathrm{ab}}$ & $29.27^{\mathrm{bc}}$ \\
\hline Control & $2.31^{\mathrm{c}}$ & $2.17^{\mathrm{b}}$ & 43.79 & 47.96 & $30.63^{b}$ & $28.00^{\mathrm{c}}$ \\
\hline Mean & 3.38 & 3.45 & & & 32.64 & 31.25 \\
\hline $\mathrm{CV}(\%)$ & 11.32 & 18.66 & & & 3.80 & 6.5 \\
\hline
\end{tabular}

Means shown with the same letters were not significantly different from each other

Table 5 Correlation coefficients ( $r$ ) of disease parameters with yield

\begin{tabular}{|c|c|c|c|c|c|c|c|c|c|c|c|c|}
\hline \multirow{3}{*}{ Parameters } & \multicolumn{6}{|c|}{ Lay Gorebela } & \multicolumn{6}{|c|}{ Basona worana } \\
\hline & \multicolumn{3}{|c|}{$2014 / 15$} & \multicolumn{3}{|c|}{$2015 / 16$} & \multicolumn{3}{|c|}{$2014 / 15$} & \multicolumn{3}{|c|}{$2015 / 16$} \\
\hline & Yield & AUDPC & PSI & Yield & AUDPC & PSI & Yield & AUDPC & PSI & Yield & AUDPC & PSI \\
\hline & --- & ------ & ----- & ----- & ------ & $\begin{array}{ll}---- \\
\end{array}$ & ------ & ------ & $\begin{array}{ll}---- \\
--1\end{array}$ & ----- & ------ & ----- \\
\hline AUDPC & $.737 * *$ & ------ & ----- & $-0.758 *$ & ------ & ----- & $-0.80 * *$ & ------ & ----- & $-0.605^{*}$ & ------ & ----- \\
\hline PSI & $-0.695 * *$ & $0.888 * *$ & ----- & $-0.615 *$ & $0.960 * *$ & ----- & $-0.79 * *$ & $0.951 * *$ & ----- & $-0.753 *$ & $0.976 * *$ & ----- \\
\hline
\end{tabular}

Table 6 Partial budget analysis of fungicide application at Lay Gorebela

\begin{tabular}{|c|c|c|c|c|c|c|c|c|}
\hline \multirow{2}{*}{ Fungicides } & \multicolumn{4}{|c|}{$2014 / 15$} & \multicolumn{4}{|c|}{$2015 / 16$} \\
\hline & AY & $\mathrm{P}$ & $\mathrm{VC}$ & NP & $\mathrm{AY}$ & $\mathrm{P}$ & $\mathrm{VC}$ & NP \\
\hline Chlorothalonil & 3.41 & 8898 & 3645 & 26706.08 & 2.808 & 13500 & 3645 & 34263 \\
\hline Mancozeb $80 \%$ WP & 3.4 & 8898 & 1170 & 29127.42 & 2.925 & 13500 & 1170 & 38317.5 \\
\hline Triadimefon $250 \mathrm{~g} / 1$ & 3.73 & 8898 & 1020 & 32160.38 & 3.573 & 13500 & 1020 & 47215.5 \\
\hline Metalaxyl-M 68\% WG & 3.46 & 8898 & 2970 & 27807.92 & 2.97 & 13500 & 2970 & 37125 \\
\hline Metalaxyl 8\% + Mancozeb 64\% WP & 3.81 & 8898 & 2670 & 31204.69 & 3.141 & 13500 & 2670 & 39733.5 \\
\hline Fludioxonil & 3.13 & 8898 & 1090 & 26724.88 & 2.583 & 13500 & 960 & 33910.5 \\
\hline Control & 2.72 & 8898 & 0 & 24211.19 & 2.502 & 13500 & 0 & 33777 \\
\hline
\end{tabular}

AY: Adjusted yield $\left(\mathrm{t} \mathrm{ha}^{-1}\right)\left(\mathrm{YLD}^{*} 0.90\right)$, P: Price $\left(\mathrm{ETB} \mathrm{ton}^{-1}\right), \mathrm{VC}$ : Variable cost $\left(\mathrm{ETB}^{-1} \mathrm{ha}^{-1}\right)$, NP: Net profit $\left(\mathrm{ETB}^{-1}\right.$ ton $\left.^{-1}\right)$

Table 7 Partial budget analysis of fungicide application at Mush

\begin{tabular}{l|cccccccc}
\hline \multirow{2}{*}{ Fungicides } & \multicolumn{4}{c}{$2014 / 15$} & \multicolumn{3}{c}{$2015 / 16$} \\
\cline { 2 - 8 } & AY & P & VC & NP & AY & P & VC & NP \\
\hline Chlorothalonil & 3.15 & 8909.95 & 3675 & 24391.3 & 2.97 & 13500 & 3675 & 36420 \\
Mancozeb 80\% WP & 3.04 & 8909.95 & 1200 & 25904.1 & 3.114 & 13500 & 1200 & 40839 \\
Triadimefon 250 g/l & 3.3 & 8909.95 & 1050 & 28353.1 & 3.708 & 13500 & 1050 & 49008 \\
Metalaxyl-M 68\% WG & 3.2 & 8909.95 & 3000 & 25521 & 3.321 & 13500 & 3000 & 41833.5 \\
Metalaxyl 8\% + Mancozeb 64\% WP & 3.67 & 8909.95 & 2700 & 30257.9 & 3.753 & 13500 & 2700 & 47965.5 \\
Fludioxonil & 2.83 & 8909.95 & 960 & 24246 & 2.934 & 13500 & 960 & 38649 \\
Control & 2.08 & 8909.95 & 0 & 18523.8 & 1.953 & 13500 & 0 & 26365.5 \\
\hline
\end{tabular}

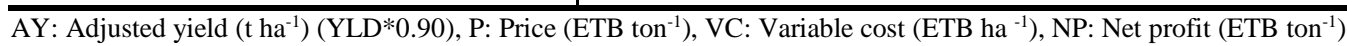




\section{Summary and Conclusion}

The current study indicated that application of Triadimefon $250 \mathrm{~g} /$ land Metalaxyl 8\% + Mancozeb 64\% WP lowered "faba bean gall" intensity, AUDPC, disease progress rate of the disease and yield loss. Application of these fungicides gave high yield and net profit than the other treatments. Considering economical benefits, application of three sprays of Triadimefon $250 \mathrm{~g} / 1$ and Metalaxyl 8\% + Mancozeb 64\% WP were profitable. Thus, it is recommended to use these fungicides as they gave the best protection against "faba bean gall" and the best monetary benefit as compared to the other fungicides and the unsprayed control.

At the time, if chemotherapeutic measures are intelligently applied and accompanied by development of integrated management package, including host plant resistance, in the research system, production as well as productivity and conservation of genetic resource could be substantially improved in faba bean (Vicia faba) in Ethiopia-the secondary origin of the species. The disease is now considered as a priority bio-security threat to the food legumes industry in the country.

\section{Acknowledgments}

This study was financed by International Centre for Agricultural Research in the Dray Areas (ICARDA) through ADA project (Australian Development Agency). We are thankful to Daniel Admasu, Zerihun Kebede, Kibnesh Girma and Fikrey Tesfaye for assistance in field work, laboratory work and write up. We thank Holleta Agricultural Research Center for providing us with faba bean seeds.

\section{References}

Alemu GY, Tadele YA. 2017. Management of Faba Bean Gall Disease through the use of Host Resistance and Fungicide Foliar Spray in Northwestern Ethiopia. Adv Crop Sci Tech 5:254. doi: 10.4172/2329-8863.1000254

Belachew tadesse. 2016. Assessment of faba bean gall disease intensity and its management using cultivars and fungicides in north shoa zone of central Ethiopia. MSc. thesis,Ambo university, Ambo, Ethiopia.

Berger RD. 1981. Comparison of the Gompertz and Logistic equation to describe plant disease progress. Phytopathology, 71: 716-719.

Beyene B, Abiro T. 2016. Management of Faba Bean Gall Disease (Kormid) in North Shewa Highlands, Ethiopia. Adv Crop Sci Tech 4:225. doi:10.4172/2329-8863.1000225.

Beyene B. 2015. Survey and identification of new faba bean disease (Qormid) in the highlands of North Shewa, Ethiopia. $C R M B, 3: 561-563$.

Beyene B, Wulita W. 2012. New faba bean disease in North Shewa-Ethiopia: 'Faba bean leaf and stem gall'. http//www.arari.gov.et/index.php?option Accessed on 01 June 2014.
Campbell CL, Madden VL. 1990. Introduction to Plant Disease Epidemiology. Wiley, New York, USA. 532 pp.

CIMMYT. 1988. International Maize and Wheat Improvement Center. From agronomic data to farmers' recommendations: Economic training mannual.79 pp.

CSA. 2014. Central Statistical Agency. Report on area and production of major crops (private peasant holdings, meher season). Statistical Bulletin, 1 (532): 10-14.

DBARC. 2015. Debre Birhan Agricultural Research Center. Progress report for the period 2015, Debre Birhan.

Dereje G, Wondafrash M, Gemechu K. 2012.Faba Bean Galls: A new disease of faba bean in Ethiopia. Available at Google.doc.com,pp 1-6.

Ding G, Xung L, Oifang G, Pingxi L, Dazaho Y, Ronghai H. 1993. Evaluation and screening of faba bean germplasm in China. FABIS Newsletter, 32: 8-10.

Endale H, Gezahegne G, Tadesse S, Negussie T, Beyene B, Anteneh B, Daniel K, TameneT. 2014. Faba Bean Gall; a New Threat for Faba Bean (Viciafaba) Production in Ethiopia. Adv Crop Sci Tech 2:144. doi: 10.4172/23298863.1000144.

Huazhi YE. 2014. Results of identification on Faba bean Galls Specimens from Ethiopia. Personal communication. Sichuan Agricultural University 46 Xinkang Road,Yaan,625014 Sichuan, China.

Li-juan L, Zhao-hai Y, Zhao-jie Z, Ming-shi X, Han-qing Y. 1993. Faba Bean in China: State-of-the-art Review Special Study Report (English Translation). International Center for Agricultural Research in the Dry Areas (ICARDA) P.O. Box 5466, Aleppo, Syria.

Rechcing NA, Rechcing JE. 1997. Environmentally Safe Approaches to Crop Disease Control. CRC, Lewis Publishers, New York.

Samuel S, Seid A, Chemeda F, Abang MM, Sakhuja PK. 2008. Survey of chocolate spot (Botrytyfabae) disease of faba bean (ViciafabaL.) and assessment of factors influencing disease epidemics in northern Ethiopia. $\mathrm{Cr} \mathrm{Pr}, 27$ : 1457-1463. Doi.10.1016/j.cropro.2008.07.011.

Samuel S, Chemeda Fininsa PK, Sakhuja \& Seid A. 2010. Yiel dloss of faba bean (Vicia faba) due to chocolate spot (Botrytis fabae) in sole and mixed cropping systems in Ethiopia, Archives of Phytopathology and Plant Protection, 43:12, 1144-1159, DOI: 10.1080/03235400802343791.

SAS. 2002. Statistical Analysis System software, Version 9 Inc. Carry, North Carolina. USA

Shanner G, Finney R. 1977. Inheritance of slow-mildewing resistance in wheat proceedings. American Phytopathological Society, 2: $49 \mathrm{pp}$.

Sul H, Hwang SF, Chang KF, Conner RL, Xue AG, Warkentin TD, Blad SF, Turnbull GD. 2006. Assessment of yield loss caused by Mycosphaerella blight in field pea crops in western Canada. Journal of Plant Diseases and Protection, 113 (6): 267-274.

Teklay A, Tsehaye B, Yemane N, Assefa W. 2014. The Prevalence and Importance of Faba Bean Diseases with Special Consideration to the Newly Emerging "Faba Bean Gall" in Tigray, Ethiopia. Discourse Journal of Agriculture and Food Sciences, 2 (2): 33-38.

Van der Plank JE. 1963. Plant diseases: Epidemics and control. Academic Press, New York. 334 pp.

Wheeler BEJ. 1969. An Introduction to plant diseases.Wiley and Sons, London.374 pp.

Xing Z. 1984. Faba bean gall disease caused by Oplidium and its control. Acta Phytopathological Sinica, 14(3):165-173. 